[Folklore in space and time: the chosen articles].

(Ed.). S. Smoliak. Ternopil, 228 p. [in Ukrainian].

3. Hrom, H. (2002). Nahujevychi [Nahujevychi]. Drohobych. [in Ukrainian].

4. Hrom, H. (1992). Nahujevychi-Bat'kivshchyna Ivana Franka [Nahujevychi - motherland of Ivan Franko]. 68 p.[in Ukrainian]

5. Dobrianska, L.(2007). Expedytsija Lvivskoji konservatoriji v selo Ivana Franka [Expedition of the Lviv conservatory in the village of Ivan Franko]. Ethnomusic (Ed.). Bohdan Lukaniuk. Lviv, pp. 123 - 147. [in Ukrainian].
6. Narodni pisni z butkivshchyny Ivana Franka (2003). [Folk songs from the motherland of Ivan Franko]. (Ed.). Vasyl Sokil. Lviv, 407 p. [in Ukrainian]. 7. Smith Entoni, D. (2010). Kulturni osnovy natsij. Ijerurkhija, zapovit i respublika [The cultural Foundations of Nations: Hierarchy, Covenant, and Republik]. Kyiv, 312 p. [in Ukrainian].

8. Khaj, M. (2007). Muzychno-instrumentalna kultura ukrajintsiv (folklorna tradycija) [Musically-instrumental culture of Ukrainians (folklore tradition)]. Kyiv - Drohobych. 537 p. [in Ukrainian].

Стаття надійшла до редакції 02.08.2019

УДК 373.3.091.322

DOI:

Іван Василиків, кандидат педагогічних наук, старший викладач кафедри математики, інформатики та методики їх викладання у початковій школі, магістр факультету початкової та мистецької освіти Дрогобицького державного педагогічного університету імені Івана Франка

\title{
ЗАСТОСУВАННЯ ІНФОРМАЦЙНИХ ТЕХНОЛОГІЙ ДЛЯ РОЗВИТКУ ТВОРЧОГО МИСЛЕННЯ УЧНІВ НА УРОКАХ І В ПОЗАКЛАСНІЙ РОБОТІ В ПОЧАТКОВІЙ ШКОЛІ
}

У статті досліджується те, щуо в освіті нашої краӥни існує реформа, яка спрямована на оновлення ї̈ змісту, на вдосконалення технології освіти. Це процес, щуо триває, оскільки він пов'язаний з прогресом суспільства і на кожному етапі розвитку конкретні завдання для школи визначаються на різних рівнях.

Центром ицих процесів у середній школі є особистість вчителя. Без підготовки нового покоління вчителів, які піднімуть свій професійний та культурний рівень, неможливо внести принципові зміни в освіту. Особлива увага приділяється вчителям початкових класів, оскільки вік учнів 1 - 4 класів, на думку психологів, - ие вік, у якому вони розвивають певні риси особистості, пов 'язані з психічним розвитком.

Ключові слова: інформачійні технологї; початкова школа; презентація; творче мислення.

Puc. 3. Лim. 10.

Ivan Vasylykiv, Ph.D.(Pedagogy), Senior Lecturer of the Mathematics, Computer Science and Teaching Methods in Elementary School Department, Master of Arts in Elementary and Art Education Drohobych Ivan Franko State Pedagogical University

\section{THE IMPLEMENTATION OF INFORMATION TECHNOLOGIES FOR DEVELOPMENT OF CREATIVE THINKING OF PUPILS AT THE LESSONS AND DURING AFTER CLASS ACTIVITIES IN PRIMARY SCHOOL}

The author states that the reform in education of our country aimed at updating its content and improving the technology of education. It is an ongoing process because it is linked to the progress of society and at each stage of development; specific tasks for the school are defined at different levels.

The center of these processes in high school is the personality of the teacher. Without the preparation of a new generation of teachers who will raise their professional and cultural levels, it is impossible to make fundamental changes in education. Particular attention is paid to elementary school teachers, because the age of students of grades $1-4$, according to psychologists, is the age at which they develop certain personality traits related to mental development.

An indispensable component of the teachers' modern education is mastering the modern technologies of obtaining and disseminating new information to students. Thirty years ago, both the student and the teacher lived in a rather slow world with stable programs, textbooks, and the state system of providing textbooks from the development of the entire course of lessons, instructional films, movies, educational television and more. On the one hand, it provided for the necessary and, on average, a sufficiently good organization of the educational process, on the other, it did not contribute to the teacher's creativity and autonomy in the student's learning and impeded his initiative. 
Over the years, we have learned that in addition to the lessons learned, there are many learning avenues that will lead to success, while stimulating the initiative and creativity of the teacher and, above all, the student. Educational requirements have changed. Current and future generations need a dynamic education system that is more closely connected to their lives, with the challenges that face an ever-increasing human life.

Keywords: information technologies; Elementary School; presentation; creative thinking.

П остановка проблеми. Сьогодні до школи приходять нові покоління дітей, які живуть в інформативному, динамічному та емоційно напруженому середовищі. Таким чином, інформаційні технології стають потужним багатофункціональним засобом навчання. Їх використання вчить учня жити в інформаційному середовищі та допомагає залучати учнів до інформаційної культури.

Завдяки використанню IT навчальне середовище може бути доповнене відео, звуком та анімацією. Все це суттєво впливає на емоційну сферу молодшого школяра та сприяє підвищенню пізнавальної активності, інтересу до навчання та навчанню загалом та активізації навчальної діяльності учня. Крім того, молодші школярі вже готові працювати з IT: вони знають, що таке комп'ютер, у більшості випадків знають, як ним користуватися тощо.

Аналіз останніх досліджень і публікацій. Застосовування інформаційних технологій у навчальній діяльності присвячені дослідження Г.А. Бордовського, Р.С. Гуревича, А.М. Довгялло, І.Б. Горбунової, М.І. Жалдак [1], В.О. Ізвозчикова, М.Ю. Кадемії, В.І. Клочка, Л.Л. Коношевського, Н.В. Морзе [6], С.В. Панюкової, Н. Петлюшенко [7], I.В. Роберт, А.В. Смірнова, В.I. Сумського та ін.

Мета нашої роботи: розглянути аспекти впровадження IT технологій в початкову школу.

Виклад основного матеріалу. Школа - це лабораторія, де учні навчаються, відкриваючи можливості для кожної дитини та розвиваючи їх творчий потенціал. Зрештою, людина починає 3 матері і разом з учителем віддаляється від неї. I саме вчитель може навчити та просувати творчу особистість.

Коли вчитель починає роботу, він повинен спочатку подумати про дітей і пам'ятати, що вони принесуть радість.

Інформаційні технології покликані зменшити складність використання інформаційних ресурсів.

Сьогодні комп'ютерні інформаційні технології можна розглядати як новий спосіб спілкування 3 новим змістом батьківства та розвитку дітей. Цей метод дозволяє дитині вчитися з пристрастю та інтересом, розвиває розумову діяльність учнів [8].

Використання IT охоплює такі сфери:

- навчальну діяльність;

- позакласну роботу.
Впровадження IT відбувається за такими напрямками:

- створення презентацій, відео та аудіофайлів, слайдів із фотографіями для класу;

- використання готових навчальних програм;

- робота з Інтернет-ресурсами;

- розробка та використання власних авторських програм.

Використання IT у навчальному процесі дозволяє:

- візуалізувати навчальні матеріали;

- поліпшити якість навчального матеріалу;

- підвищення пізнавальної активності;

- поліпшення навчальних ефектів;

- застосовувати диференційований підхід до учнів з різним рівнем підготовки до навчання [6].

На веб-сайтах вчитель вибирає зображення для своїх уроків: фотографії, звукові ефекти, відео, фільми тощо.

Для уроків з української мови, математики, природознавства вчитель створює власний матеріал. Одним із таких інструментів $\epsilon$ PowerPoint. Презентація дозволяє вчителю проілюструвати свій матеріал. Це допомагає уникнути перевантаження зорового простору, зосереджуючи увагу на досліджуваному об'єкті. Крім того, вчитель може повернутися до будьякого елемента уроку, витративши мінімальну кількість часу на гіперпосилання.

Презентації ефективно використовуються на різних етапах уроку, а візуальне сприйняття об'єктів, які підлягають обстеженню, дає змогу швидше та глибше зрозуміти навчальний матеріал. Наприклад, у третьому класі ми вивчаємо тему “Як людина пізнає природу?” на уроці з природознавства, рис. 1. Презентація хороша для пояснення нового матеріалу [9].

Створюючи слайди, рекомендується використовувати анімацію, яка дозволяє вчителю поетапно будувати навчальний матеріал. Підбір елементів, які переміщуються по слайду, привертає увагу учнів до основного матеріалу навчального предмету тощо [4].

На уроках математики вчитель створює презентацію для кращого навчання (рис. 2).

За допомогою IT вчитель може перенести частину своєї роботи на комп’ютер.

Зауважте, що комп'ютер не замінює вчителя, а лише його доповнює. Вибір навчальних ігор залежить насамперед від поточного навчального 


\section{ЗАСТОСУВАННЯ ІНФОРМАЦЙНИХ ТЕХНОЛОГІЙ ДЛЯ РОЗВИТКУ ТВОРЧОГО МИСЛЕННЯ УЧНІВ НА УРОКАХ І В ПОЗАКЛАСНІЙ РОБОТІ В ПОЧАТКОВІЙ ШКОЛІ}
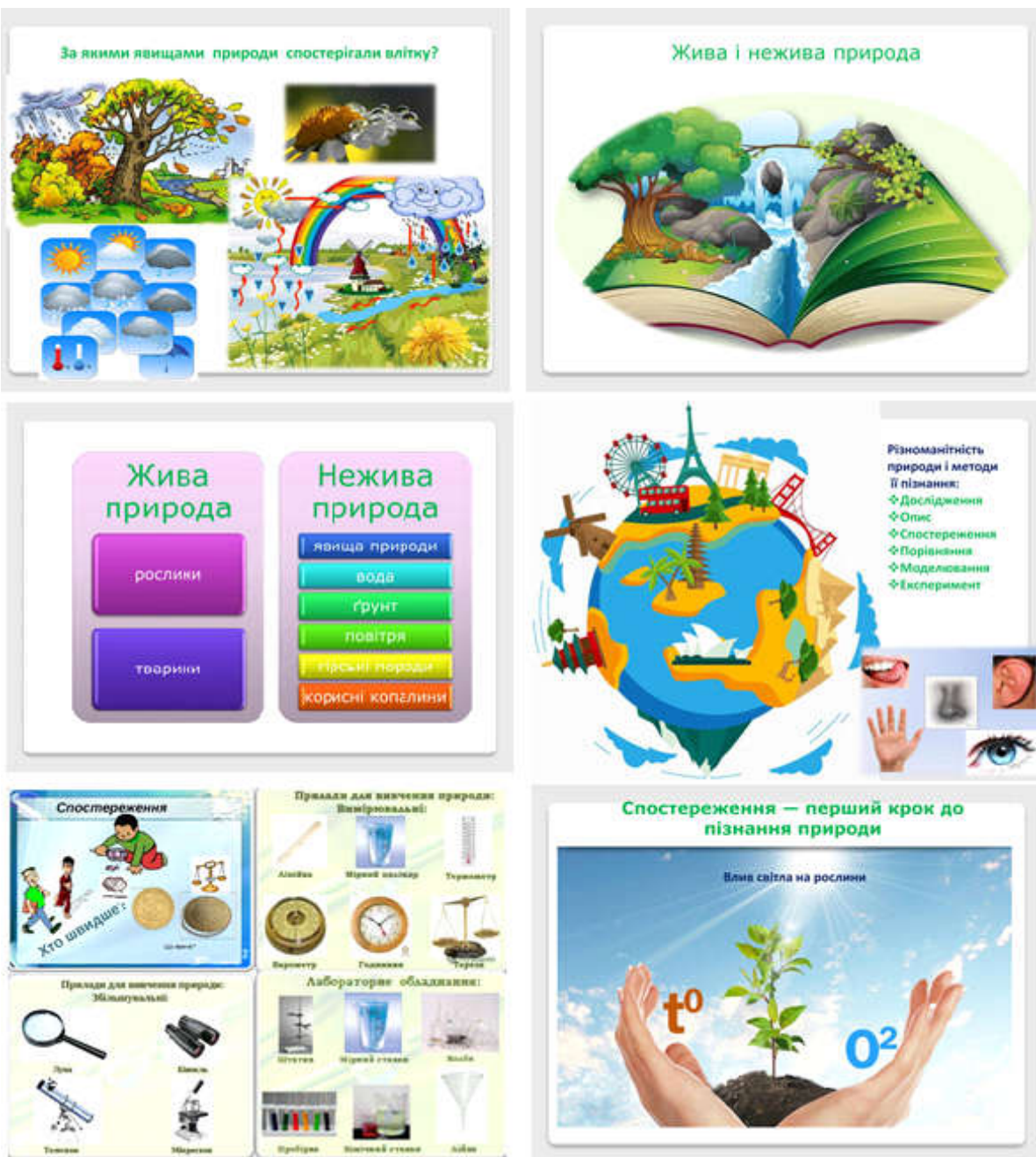

Рис. 1. Презентація уроку з природознавства на тему “Як людина пізнає природу?”

матеріалу та рівня освіти учнів. Завдяки різноманітним розробкам програмного забезпечення та освітніх програм, є можливість вибрати викладача, який творчо працює, і ви можете використовувати його 3 різними навчальними програмами та навчальними посібниками.

Наприклад, коли учні третього класу вивчають дикі гриби, вони можуть використовувати Microsoft PowerPoint для створення презентації як джерела інформації [5].

Для кращого сприйняття та кращого засвоєння дітьми будови та відтворення грибів вчителі можуть використовувати інтерактивні плакати (рис. 3).

Цей вид діяльності дозволяє вчителю проявити творчість та індивідуальність, щоб уникнути формального підходу до викладання.

Підготовка презентації-це серйозний, творчий процес, який вимагає продумати та зрозуміти кожен елемент, щоб учні могли його зрозуміти.
Інформаційні технології зручно використовувати під час уроку, що одразу стає цікавішим та кориснішим для дітей. Вчителі використовують презентацію, щоб провести годину спілкування, позашкільний захід. Багато фотографій, відеозаписів, музики роблять її цікавою для всіх дітей класу. Учні також активно беруть участь у підготовці таких заходів. Матеріал для тематичних годин спілкування можна знайти в Інтернеті через пошукові системи, газети, літературу та інші джерела [3].

Використання IT у навчальній діяльності допомагає:

- розвиток інтересу учнів до заходу;

- розвиток знань про інформаційні ресурси;

- ефективне управління увагою для студентів;

- активізація пізнавальної діяльності;

- дослідження розвитку навичок;

- підвищення інформаційної культури [11].

Учні набувають досвіду, підвищуючи свою самооцінку, оскільки вміння працювати 3 

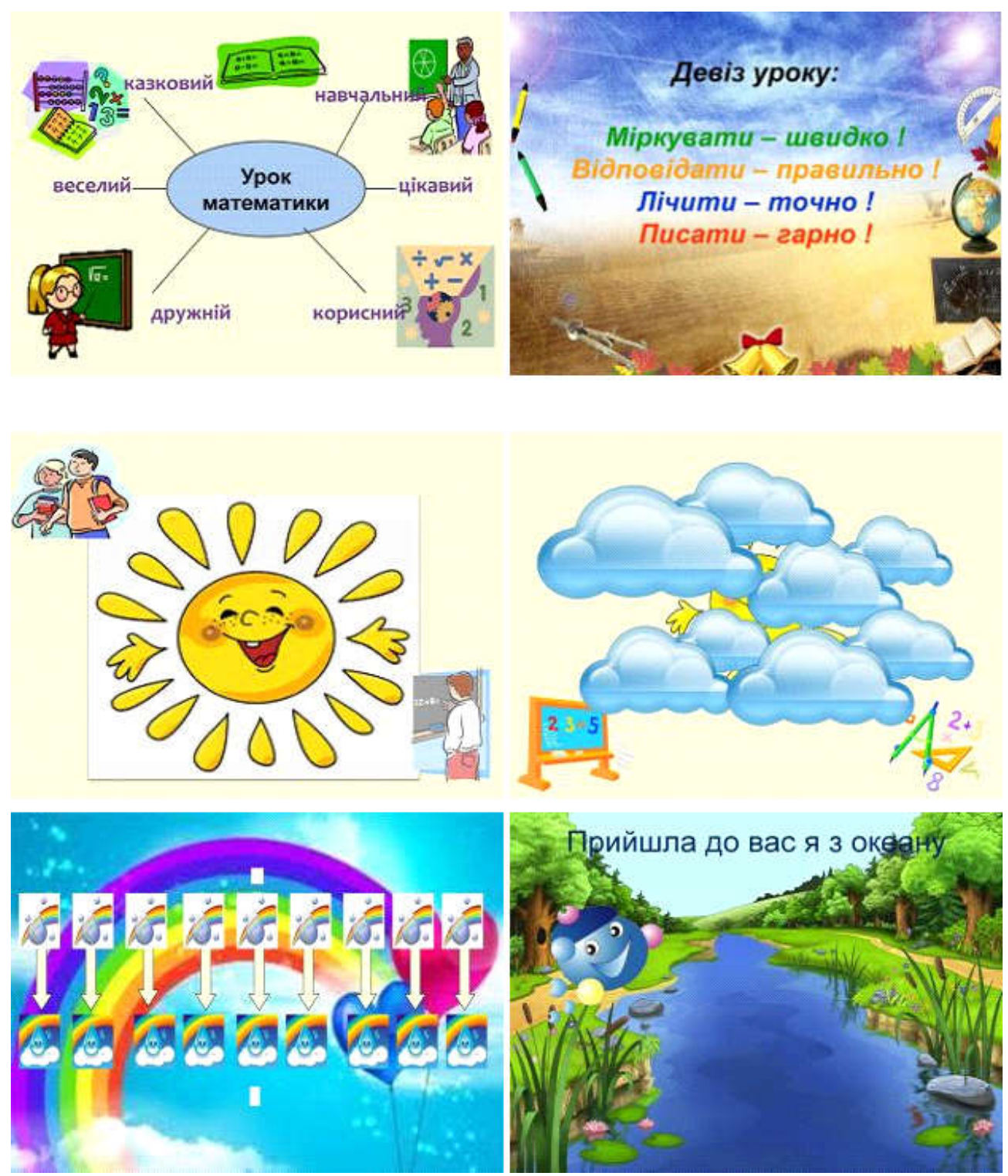

Рис. 2. Презентація до уроку математики у 2 класі на тему “Закріплення додавання і віднімання двоцифрових чисел, розв'язування задач"

комп’ютерами є елементом сучасної молодіжної культури.

Готуючи та проводячи позакласні заходи зі своїми учнями, учителю краще використовувати програми, такі як MSPowerPoint, MSPublisher, графічний редактор Adobe Photoshop, музичний плеєр тощо, щоб зробити позакласну роботу неперевершеною та незабутньою [9].

Уроки використання IT допомагають розвивати самооцінку, знання та вміння учнів та розвивати їхню здатність розпізнавати сильні та слабкі сторони їх особистості та характеру. Використання IT в освіті надає широкі можливості для реалізації різних проектів.
Нові, найсучасніші технології допомагають не лише в роботі з дітьми, а й з їхніми батьками. Часто доводиться мати справу з батьками. Не секрет, що більшість батьків не люблять відвідувати батьківські збори. Завжди є причини, через які вони не можуть (або не хочуть бути) присутніми. Завдання класного керівника зібрати їх усіх. Існує багато способів вирішити цю проблему. Одне - використання IT. Використовуючи фото і відеоматеріали $з$ життя класу, презентації з різних тем, пропонуючи діаграми успішності і якості знань, можна зробити батьківські збори яскравою подією. Кожному 3 батьків вручити “Пам'ятку для батьків”, 


\section{ЗАСТОСУВАННЯ ІНФОРМАЦЙНИХ ТЕХНОЛОГІЙ ДЛЯ РОЗВИТКУ ТВОРЧОГО МИСЛЕННЯ УЧНІВ НА УРОКАХ І В ПОЗАКЛАСНІЙ РОБОТІ В ПОЧАТКОВІЙ ШКОЛІ}
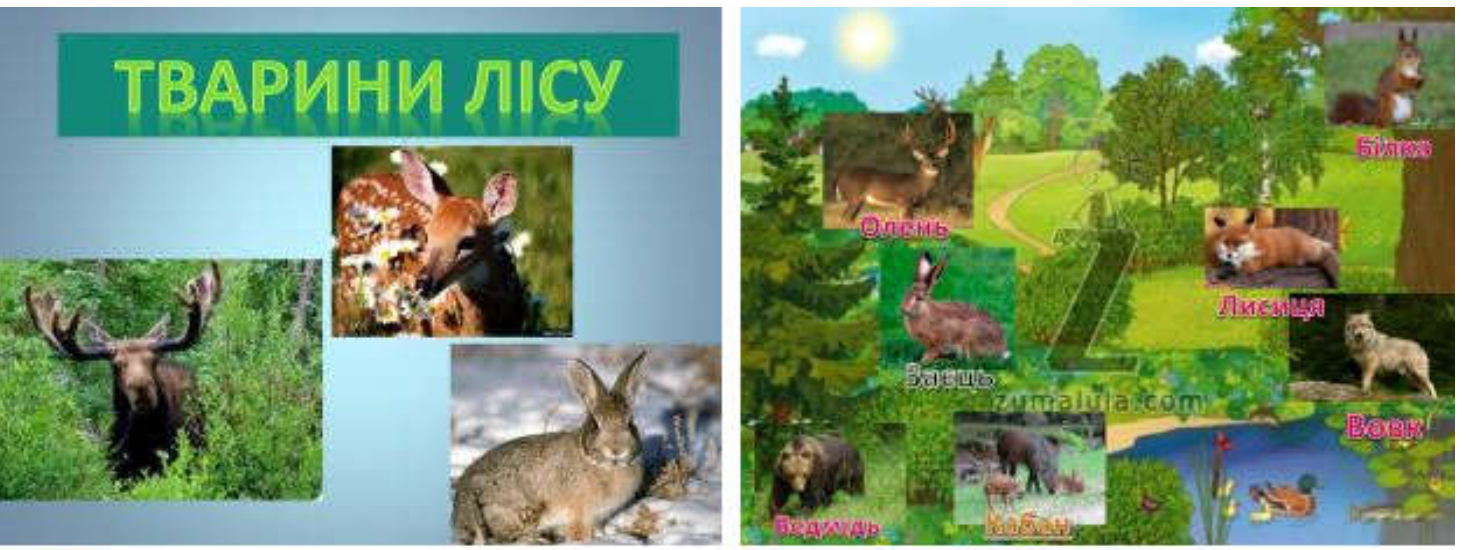

Рис. 3. Інтерактивний плакат з теми “Тварини лісу"

виготовлену у програмі MSPublisher, де записати найважливіші новини та проблеми їхніх дітей та класу. Усі батьки захочуть відвідувати такі збори $[2]$.

Батькам та дітям корисно проводити опитування, порівнювати погляди дітей та батьків на різні теми, організовувати освітні консультації та робити індивідуалізовану роботу. Для поліпшення розуміння та взаємної довіри батьки повинні залучати один одного до життя класу та школи.

Висновки. Тому IT можна використовувати у роботі з батьками у таких сферах:

- для спілкування між учнем і вчителем;

- для батьківських зборів;

- опитування;

- створення бази даних.

Психологічну готовність дитини жити в інформаційному суспільстві потрібно давати 3 перших років навчання в школі.

Нові інформаційні технології дозволяють не лише викладати матеріал на уроці в початковій школі, а й позакласну роботу на новому рівні: розмова, канікули, позашкільні заходи, батьківські зустрічі, віртуальні поїздки в різні куточки нашої країни, щоб познайомитися із зовнішнім світом.

Класний керівник повинен бути активним разом зі своїми учнями та йти в ногу з часом, адже сучасну дитину не можна виховувати без використання освіти та сучасних комп'ютерних технологій.

\section{ЛІТЕРАТУРА}

1. Жалдак М.I., Морзе Н.В. Інформатика - 7. Експериментальний навчальний посібник для учнів 7 класу загальноосвітньої школи. Київ, 2000.

2. Завдання та ігри з інформатики. Горячєв О.В. та інші. Навчальні посібники для учнів 1, 2, 3 класів. Д.: УОН, 2000.
3. Кітаєва М. Використання мультимедійних технологій. Початкова освіта, №38, 2011, с.7.

4. Кривич Е.Я. Персональный компьютер для детей. Харкив, 2001.

5. Маркова С.С. Інформаційні технології навчання. Навчально-методичний посібник. Запоріжжя, 2012. $121 \mathrm{c.}$

6. МорзеН.В. Основи інформаційно-комунікаційних технологій. Київ, 2006. 298 с.

7. Петлюшенко Н. Упровадження комп'ютерних технологій у початковій школі. Початкове навчання і виховання, №1, 2012, с.12.

8. Пономаренко Л. Мультимедійна підтримка навчального процесу. Початкова освіта, №1-2, 2012, c. 16

9. Ривкінд Ф.М. ОКГ (Основи комп'ютерної грамотності). Посібник для учнів молодших класів (розвиваюче навчання). Київ, 1998.

10. Шиман O.I. Використання сучасних інформаційних технологій. Навчальний посібник. 2-ге вид., допов. і переробл. Запоріжжя, $2012.238 \mathrm{c}$.

\section{REFERENCES}

1. Zhaldak, M.I. \& Morze, N.V. (2000). Informatyka - 7 [Informatics - 7]. An Experimental Tutorial for the 7th Grade Students in Secondary School. Kyiv. [in Ukrainian].

2. Zavdannia ta ihry $\mathrm{z}$ informatyky [Tasks and games in computer science]. Horiachiev, O.V. et al. Tutorials for students in grades 1, 2, 3. D.: UON, 2000. [in Ukrainian].

3. Kitaieva, M. (2011).Vykorystannia multymediinykh tekhnolohii [Use of multimedia technologies]. Primary education, No.38, p.7. [in Ukrainian].

4. Krivich, Ye.Ya. (2001). Personalnyy kompyuter dlya detey [Personal computer for children]. Kharkiv. [in Russian].

5. Markova, Ye.S. (2012). Informatsiini 
tekhnolohii navchannia [Information technology training].Tutorial. Zaporizhzhia, 121 p. [in Ukrainian].

6. Morze, N.V. (2006). Osnovy informatsiinokomunikatsiinykh tekhnolohii [Fundamentals of information and communication technologies]. Kyiv, 298 p. [in Ukrainian].

7. Petliushenko, N. (2012). Uprovadzhennia kompiuternykh tekhnolohii u pochatkovii shkoli [Uprovadzhennia kompiuternykh tekhnolohii u pochatkovii shkoli [Introducing computer technology in elementary school]. Primary education and upbringing, No.1, p.12. [in Ukrainian].
8. Ponomarenko, L. (2012). Multymediina pidtrymka navchalnoho protsesu [Multimedia support for the learning process]. Primary education, No.12, p.16. [in Ukrainian].

9. Ryvkind, F.M. (1998). OKH(Osnovy kompiuternoi hramotnosti) [BCL (Basics of Computer Literacy)]. A guide for primary students (developmental learning). Kyiv. [in Ukrainian].

10. Shyman, O.I. (2012). Vykorystannia suchasnykh informatsiinykh tekhnolohii [Use of modern information technologies]. Tutorial. 2nd ed., Suppl. and redone. Zaporizhzhia, 238 p. [in Ukrainian].

Стаття надійшла до редакції 27.08.2019

УДК 377.352/354: 377.44

DOI:

Оксана Самойленко, кандидат педагогічних наук, докторант кафедри педагогіки Житомирського державного університету імені Івана Франка

\section{КВАЛІФІКАЦІЙНО-КОМПЕТЕНТНІСНИЙ ПІДХІД ДО ПІДГОТОВКИ ФАХІВЦІВ У ЗАКЛАДАХ ВИЩОЇ ОСВІТИ: ЄВРОПЕЙСЬКИЙ ДОСВІД}

У статті представлено результати розгляду кваліфікаиійно-компетентнісного підходу до підготовки фахівиів у країнах європейської співдружності з метою його перспективного застосування у практику вітчизняних закладів вищої освіти. Виявлено ефективність даного підходу через його практичну спрямованість на формування професійної компетентності фахівиів засобами інтеграції закладу вищої освіти та бізнес-структур. Доведена необхідність врахування запитів ринку праці з метою окреслення змісту навчально-пізнавальної діяльності, який призводить до професійного самовизначення слухача закладу вищої освіти.

Ключові слова: заклад вищої освіти; кваліфікаційно-компетентнісний підхід; ринок прачі.

Jim. 5.

Oksana Samoylenko, Ph.D.(Pedagogy), Doctoral Student of the Pedagogy Department Zhytomyr Ivan Franko State University

\section{THE QUALIFICATION AND COMPETENCE APPROACH TO TRAINING OF EXPERTS IN HIGHER EDUCATION INSTITUTIONS: EUROPEAN EXPERIENCE}

The article presents the results of consideration of the qualification-competent approach to the training of specialists in the countries of the European Commonwealth for the purpose of its future application into the practice of domestic higher education institutions. The basic provisions on the formation of a competent specialist in the countries of the European Union are economic, which stipulates that education should ensure: 1) mastery of future professionals with activities that meet not only professional but also social expectations; 2) the formation of their ability to conscious participation in social processes, 3) their effective socialization.

The effectiveness of this approach is revealed due to its practical orientation on the formation of professional competence of specialists by the means of integration of institutions of higher education and business structures in several stages: 1) the formation of a student's new knowledge; 2) the use of this knowledge in research activities; 3) obtaining a practical result; 4) experimentation with the practical result obtained before its implementation into the technological process of the enterprise or the production process of the business unit; 5) testing of the technological / production process.

The necessity of taking into account labor market demands is proved in order to outline the content of educational and cognitive activity, which leads to the professional self-determination of the student of the institution of higher education. In the context of the above criteria, the competitiveness of an adult in the labor market is the degree of autonomy in the implementation of activities and decision-making and the ratio of reproductive and creative components in the implementation of activities.

Promising for Ukraine is the adaptation of the qualification-competent approach to the conditions of training 